ISSN 1991- 8690

website :http:// jsci.utq.edu.iq

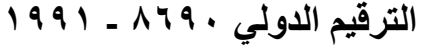

Email: utjsci@utq.edu.iq

\title{
Spectrophotometric Determination of Ranitidine-HCl in Pure Form and Pharmaceutical Formulations with Metol and potassium hexacyanoferrate (III)
} Abeer Qays Abdulwahab Chemistry Department . College Of Science . Dhi- Qar University

طريقة بسيطة عالية الحساسية وذات دقة عالية لتقدير الرانيتدين بشكل نقي او في المستحضرات الصيدلانية من خلال تكوين معقد تضمنت الطريقة تفاعل الرانيتيدين مع مزيج الميتول وبوتاسيوم سداسي سيانيد الحديديك وتكوين معقد ملون لتقدير الرانيتدين طيفيا عند اقصى طول موجي ، ؛ه نانوميتر تم تحديد الظروف الفضلى للتفاعل للحصول على اعلى حساسية و اطول استقرارية عند الظروف الفضلى للامتصاصية للمعقد الملون وجد زيادة بالخطية مع

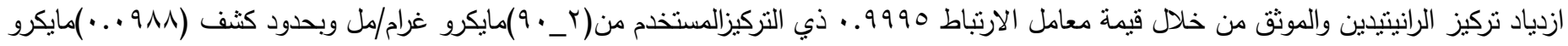
غرام/مل وبانحراف نسبي ( ال • ) طبقت الطريقة المقترحة بدقة وضبط عالي وبنجاح لتقدير نسبة الرانتدين بشكل نقي اوفي المستحضرات الصبدلانية وتم مقارنة النتائج الاحصائية باستخدام اختباري F+t وقد وجد ان قيمها اقل من قيمهما الواردة بالطريقة المستخدمة باللاستور البريطاني .

\section{$\underline{\text { Abstract }}$}

A simple, sensitive and accurate spectrophotometric method of determination of Ranitidine-HCl (RNH) in pure form and its pharmaceutical formulation. Was used in this studyThe method is based on the formation of (RNH) complex. The reaction between the Ranitidine- $\mathrm{HCl}$ with the mixture of metol and potassium hexacyanoferrate (III) was evaluate metol ( Nmethyl - p-aminophenosulphate ) for the spectrophotometric determination of the Ranitidine $\mathrm{HCl}$. The maximum absorbance of the colored complex occurred at $\lambda=540 \mathrm{~nm}$. Reaction conditions have been optimized to obtain (RNH) complex of high sensitivity and longer stability. Under optimum conditions the absorbance of the (RNH) complex where found to increase linearly with the increase in concentration of the Ranitidine- $\mathrm{HCl}$ which corroborated with correlation coefficient value. Of 0.09995 with concetration ranges of $(2-90) \mu \mathrm{g} / \mathrm{ml}$ relative standard deviation and relative error of prediction for drug were lower. The proposed method was successfully applied to determine of the selected Ranitidine- $\mathrm{HCl}$ in pure form and pharmaceutical formulations with good precision and accuracy compared to standard method as revealed by $\mathrm{t}$ - and F- values, the results obtained agree well with the labeled contents.

\section{Introduction}

Ranitidine hydrochloride (RNH), chemically $\mathrm{N}, \mathrm{N}$ dimethyl-5-(2-(1-methylamine-2-nitrovinyl)ethylthiomethyl) furfurylamine hydrochloride. It is a $\mathrm{H} 2$-receptor antagonist and is widely used in short term treatment of duodenal ulcer and in the management of hypersecretory conditions . It acts by blocking histamine receptors which are present on the cells in the stomach lining. Ranitidine binds to $\mathrm{H} 2$ receptors, replacing some of thehistamine. As a result, the amount of stomach acid produced by these cells is decreased. Ranitidine decreases the amount of acid in the stomach and duodenum. Ranitidine helps relieve the symptoms of indigestion and aids the healing of ulcers. It is also used to depress acid production in various other conditions [1].The molecular formula is $\mathrm{C} 13 \mathrm{H} 22 \mathrm{~N} 4 \mathrm{O} 3 \mathrm{~S} \cdot \mathrm{HCl}$, representing a molecular weight of $350.87 \mathrm{~g}$ mol. It is a white to pale yellow, crystalline substance that is soluble in water.

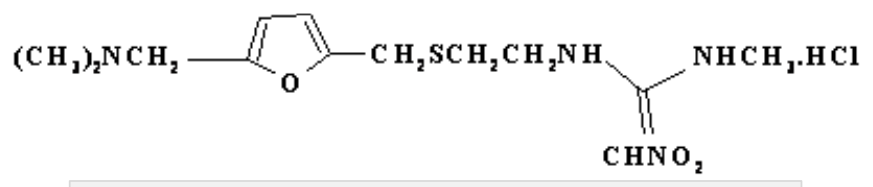

Fig. 1: Structural formula of RNH drug

Several methods have been reported for the determination of Ranitidine- $\mathrm{HCl}$ in bulk, pharmaceutical dosage forms, and biological fluids[2]. 
These methods include kinetic spectrophotometry [3,4], HPLC [5,6],HPTLC [7],Micellarliquichromatography [8], liquidchromatographymassspectrometry $[9,10]$,liquidchr omatography[11],capillary electrophoresis [12], fluorimetry[13], flow injection analysis[14,15], voltammeter[16], potentiometer[17,18], palarography[19 ], hanging mercury drop electrode[20],FT-IR[21], AAS[22], argentimetric[23], titrimetry[24] and UVspectrophotometry[25].But such techniques are time consuming because extensive sample pretreatment, required expensive instrumentation and beyond the reach of small laboratories, particularly in under developed and developing countries.The aim of the present work is to study the charge - transfer complex reaction in developing simple, accurate, sensitive and reproducible assays to determinetionRanitidine- $\mathrm{HCl}$ in pure form and pharmaceutical formulation [26].

\section{Experimental}

\section{Apparatus}

UV-1600 PC (Shimadzu, Japan) UV Spectrophotometer with matched $1 \mathrm{~cm}$ quartz cells were used for all measurements.

\section{Materials and Reagents}

All reagents used were analytical grade and water was always double distilled.Pure samples Ranitidine$\mathrm{HCl}$ pure grade was provided by SID- Samara factory.Standard stock solutions Stock solutions of Ranitidine- $\mathrm{HCl}$ were prepared by dissolved $(0.01 \mathrm{~g})$ of Ranitidine- $\mathrm{HCl}$ in $50 \mathrm{ml}$ volumetric flasks and diluted to the mark with distill water.

\section{Market samples}

Ranitidine- $\mathrm{HCl}$ tablets, labeled to contain (20\%) were obtained from commercial sources in the local market.

\section{Reagents}

Metol solutions (13 and $20 \mathrm{mM})$ were freshly prepared by dissolved $(0.225 \mathrm{~g})$ and $(0.68889 \mathrm{~g})$ of metol respectively, and diluting to $50 \mathrm{ml}$ with distill water in volumetric flasks. $(20 \mathrm{mM})$ potassium hexacyanoferrate (III) were prepared by dissolved $(0.332 \mathrm{~g}) \mathrm{K} 3[\mathrm{Fe}(\mathrm{CN}) 6]$ and diluting to $50 \mathrm{ml}$ with distill water in volumetric flask.

\section{Recommended analytical procedure Method}

$0.1-10 \mu \mathrm{g} / \mathrm{ml}$ ofdifferent aliquots of Ranitidine- $\mathrm{HCl}$ standard stock $(100 \mu \mathrm{g} / \mathrm{ml})$ were transferred into a series of $10 \mathrm{ml}$ volumetric flasks, To each these were added $1 \mathrm{ml}$ of buffersolution $(\mathrm{pH}=5.2)$ \&metol $1 \mathrm{ml}$ and potassium hexacyanoferrate (III) $(1 \mathrm{ml})$ were diluted to the mark with distill water. The absorbance was measured at $\lambda=540 \mathrm{~nm}$ against a reagent blank prepared
similarly.A calibration graphs were drawn by plotting the absorbance against the drug concentration.

\section{Analytical of pharmaceutical formulation}

Ten tablets were accurately weighted and finally powdered. An amount of the powder equivalent (10mg) Ranitidine- $\mathrm{HCl}$ was dissolved in $100 \mathrm{ml}$ with distill water of calibrated flask. The contents of the flask were shaken and then make up to the mark with distill waterto obtain $(100 \mu \mathrm{g} / \mathrm{ml})$ of RHN.

\section{Results and Discussion}

Absorption spectra Throughout the preliminary investigation on the reaction[15], between drugs (RHN) with metol in the presence of potassium hexacyanoferrate (III), (violet colored) products obtained(Scheme-1) with a maximum absorption at $\lambda=540 \mathrm{~nm}$ (Fig. 2). The absorbance of the colored products measured against reagent blank which has minimum absorbance at the same wavelength from the results obtained, appeared that it is possible to determine no.of micrograms of this drug.

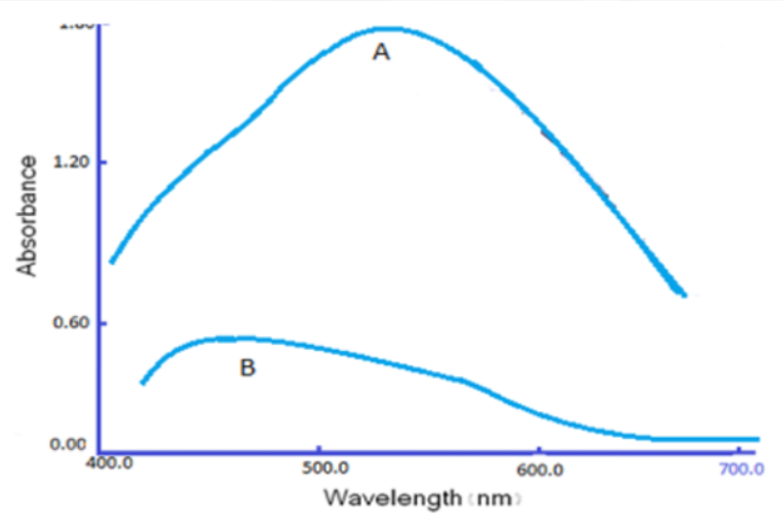

Fig. 2. Absorption spectra of $A=$ drug RanitidineHClcomplex, $\mathrm{B}=$ metol/ potassium hexacyanoferrate (III) reagent

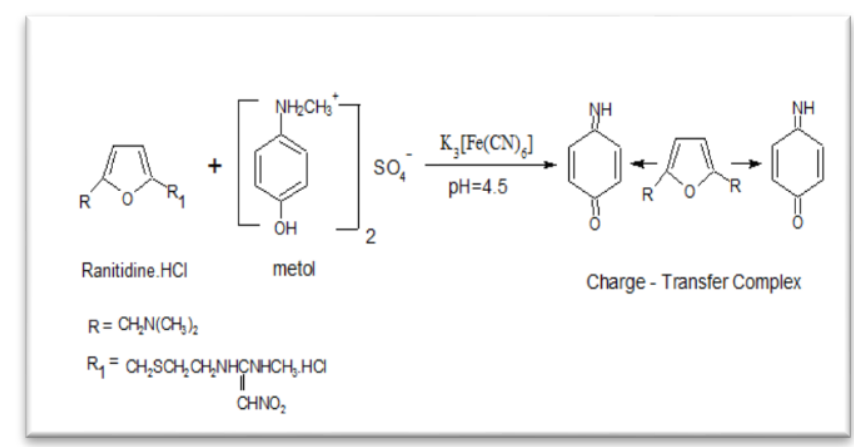

Scheme - 1 


\section{Optimization of Experimental Conditions}

The effect of various variables on the color development was tested to establish the optimum conditions for the determination of Ranitidine- $\mathrm{HCl}$ by using metol and potassium hexacyanoferrate (III) .

\section{Effect of pH}

The optimum $\mathrm{pH}$ for complete color development is

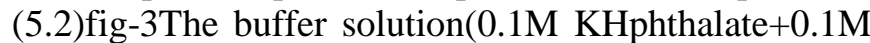
$\mathrm{HCL}$ ) is added to give the required $\mathrm{pH}$.

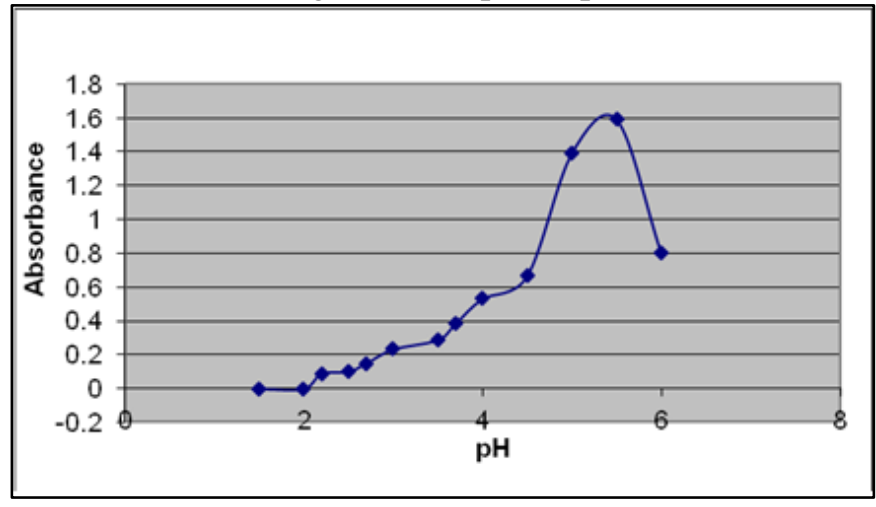

Fig. 3.Optimum pH for complete color development

\section{Effect Concentration of potassium hexacyanoferrate (III)}

The effect of the different volumes of $(20 \mathrm{mM})$ of $\mathrm{K} 3[\mathrm{Fe}(\mathrm{CN}) 6]$ solution was examined on the maximum absorbance of the color product in the presence of $(1 \mathrm{ml})$ metol $(20 \mathrm{mM})$. Fig. 5 shows that $1 \mathrm{ml}$ of the solution of potassium hexacyanoferrate (III) was enough to obtain the maximum absorbance.

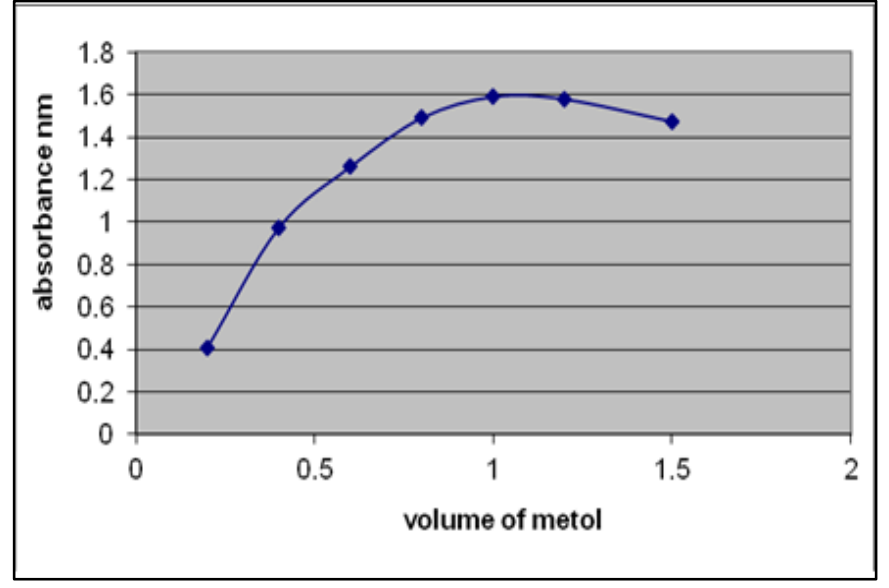

Fig. 4. Effect of volume of $(20 \mathrm{mM})$ potassium hexayanoferrate (III)on the absorbance intensity of Ranitidine- $\mathrm{HCl}$ drug at 540nm

\section{Effect volume of metol reagent}

Metol was found to be a useful for charge transfers reaction, because it was produced a stable charge transfer complexes rapidly with drugs in prescence of potassium hexacyanoferrate (III). More over this reagent is easily obtainable and is soluble in water. The effects of the different volumes of $(20 \mathrm{mM})$ metol solutions were examined on the maximum formation of the color product. Fig.6 shows that $(1 \mathrm{ml})$ of the solution was enough to obtain the maximum absorbance, and it was used in the subsequent experiments.

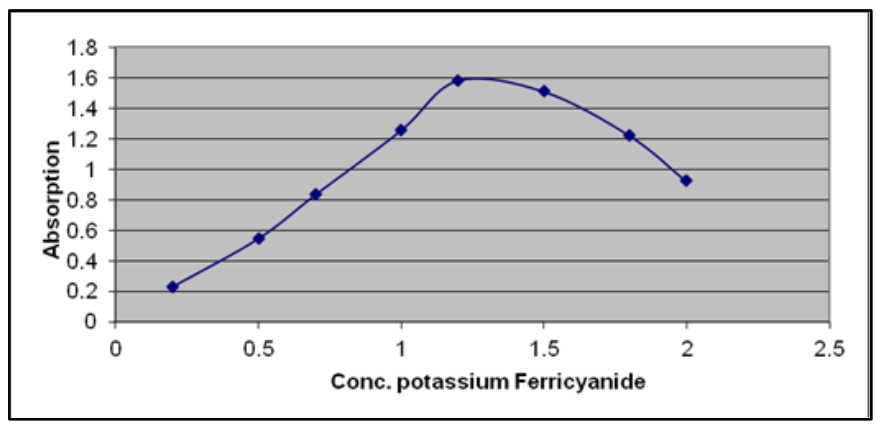

Fig- 5:Effect of volume of metol reagent $(20 \mathrm{mM})$ on the absorbance intensity of Ranitidine- $\mathrm{HCl}$ drugusin (1 $\mathrm{ml}$ ) of potassium hexacyanoferrate at $540 \mathrm{~nm}$

\section{Effect of addition Orders}

Seven orders of addition were examined as shown below in table-1:

Table 1: effect of series addition

\begin{tabular}{|c|c|c||}
\hline NO. & Addition order & Absorbance(nm) \\
\hline 1 & $\mathrm{~F}+\mathrm{M}+\mathrm{D}+\mathrm{B}$ & 0.320 \\
\hline 2 & $\mathrm{~F}+\mathrm{B}+\mathrm{D}+\mathrm{M}$ & 0.377 \\
\hline 3 & $\mathrm{~F}+\mathrm{M}+\mathrm{B}+\mathrm{D}$ & 0.410 \\
\hline 4 & $\mathrm{~B}+\mathrm{D}+\mathrm{M}+\mathrm{F}$ & $\boldsymbol{0 . 6 5 0}$ \\
\hline 5 & $\mathrm{M}+\mathrm{F}+\mathrm{B}+\mathrm{D}$ & $\mathbf{0 . 5 2 0}$ \\
\hline 6 & $\mathrm{M}+\mathrm{B}+\mathrm{D}+\mathrm{F}$ & $\mathbf{0 . 6 1 2}$ \\
\hline 7 & $\mathrm{D}+\mathrm{B}+\mathrm{M}+\mathrm{F}$ & $\mathbf{0 . 7 7 3}$ \\
\hline
\end{tabular}

$\mathrm{D}=$ Drug, $\mathrm{R}=$ Reagent (metol), $\mathrm{O}=$ Oxidant k3[Fe(CN)6] , B=buffer

\section{Effect of temperature}

The effect of temperature on the color intensity of the product was studied Fig. 7 in practice a maximum absorbance was obtained when the color was developed at room temperature $\left(25^{\circ} \mathrm{C}\right)$, but when the color was developed in an ice bath $\left(5^{\circ} \mathrm{C}\right)$ or in a water bath $\left(45^{\circ} \mathrm{C}\right)$ 
a loss in color andunstability were observed. It is therefore recommended that the color reaction should be carried out at room temperature $\left(25^{\circ} \mathrm{C}\right)$ after 20min.(Fig-8)

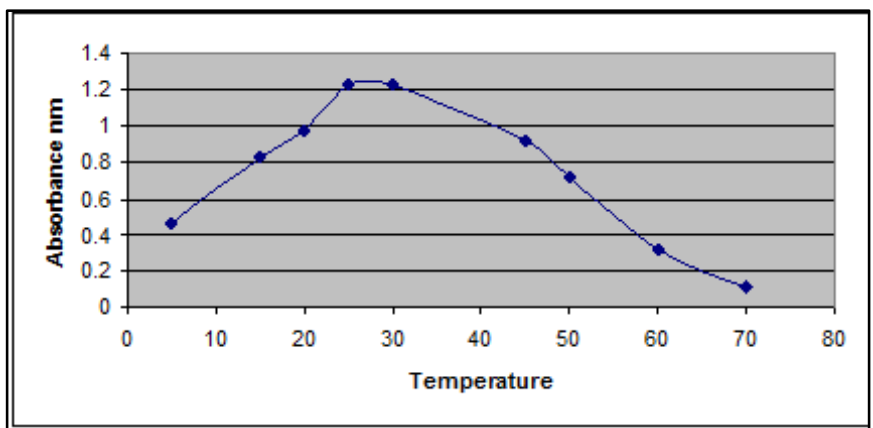

Fig.6 Effect of temperature of the valu absorbance at540nm

\section{Effect of time stability}

The color intensity reached a maximum after drug solution had been reacted immediately with metol and potassium hxacyanoferrate (III) in aqueous medium and became stable after (20min), remained stable for at least (Fig.8).

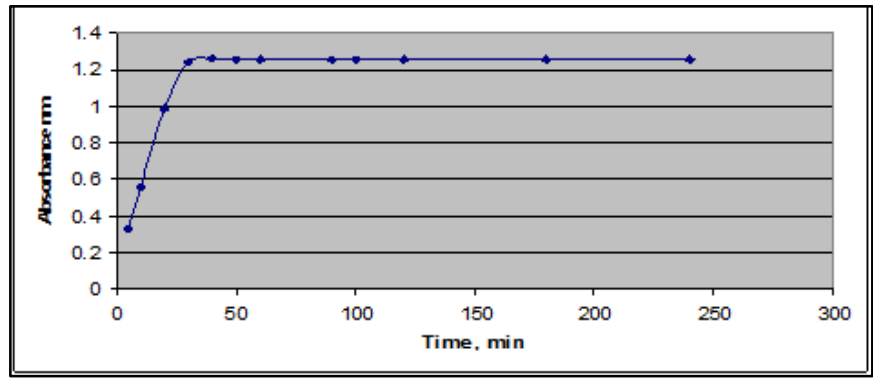

Fig.7 Effect of time (min) on the absorbance of the formed complexes of Ranitidine- $\mathrm{HCl}$ drug at 540nm

\section{Calibration Graph}

After the optimizing reactions describe above, calibration curve (Fig.9) for Ranitidine-HCl was constructed by plotting absorbance of Ranitidine- $\mathrm{HCl}$ complex and the concentration of the Ranitidine- $\mathrm{HCl}$ drug. The calibration curve was linear. The analytical values of statistical treatments for the calibration curve are summarized in table-2.
Table-2: performance analytical data of the proposed method

\begin{tabular}{|c|c|}
\hline Parameter & Value \\
\hline Correlation coefficient ${ }^{\circledR}$ & 0.9995 \\
\hline Linearity percentage $\left(\mathrm{r}^{2} \%\right)$ & 99.950 \\
\hline Test for a significant correlation ( $t$ ) & 154.906 \\
\hline Regression equation & $Y=0.0710 X+0.1174$ \\
\hline Slope $\left(\mathrm{ml} \mu \mathrm{g}^{-1}\right)$ & 0.010 \\
\hline Intercept & 0.117 \\
\hline Standard deviation of the residuals & 0.001057166 \\
\hline Standard deviation of the slope, $S_{b}$ & 0.001 \\
\hline Standard deviation of intercept Sa & 0.003 \\
\hline Linearity range $\left(\mu \mathrm{g} \mathrm{ml}^{-1}\right)$ & $2-900$ \\
\hline Molar absorptivity, $\varepsilon\left(\mathrm{l} \mathrm{mol}^{-1} \mathrm{~cm}^{-2}\right)$ & $3.144 \times 10^{5}$ \\
\hline Sandell's sensitivity, $\mathrm{S}\left(\mu \mathrm{g} \mathrm{cm}^{-2}\right)$ & $1 \times 10^{-3}$ \\
\hline Limit of detection LOD $\left(\mu \mathrm{g} \mathrm{ml}^{-1}\right)$ & 0.098 \\
\hline Limit of quantification LOQ $\left(\mu \mathrm{g} \mathrm{m}^{-1}\right)$ & 0.988 \\
\hline
\end{tabular}

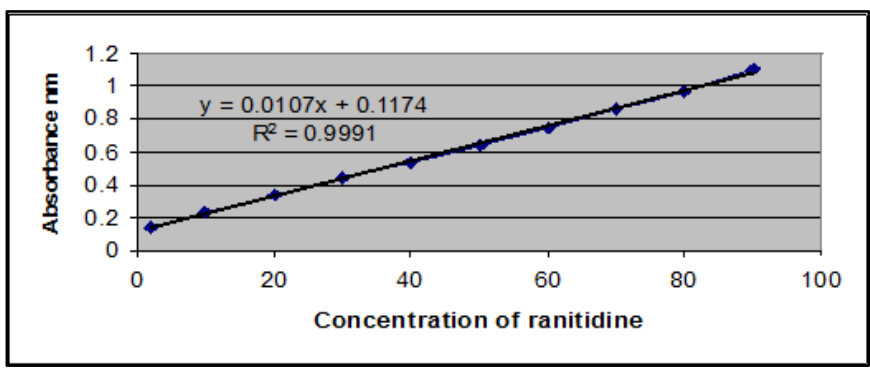

Fig.8. Calibration Curve of Ranitidine- $\mathrm{HCl}$

\section{Accuracy and precision}

The accuracy and precision of the determination of Ranitidine-HCl were studied depending upon the value percentage of the relative error (E\%), recovery (REC\%) and relative standard deviation (RSD\%). For five replicates of each concentration of Ranitidine- $\mathrm{HCl}(8$, $16,25) \mu \mathrm{g} \cdot \mathrm{ml}^{-1}$. The results in Table 3 show a good accuracy and precision.

Tabel-3: Accuracy and precision of the proposed method Average of five determinations

\begin{tabular}{||c|c|c|c|c|c|}
\hline \multirow{2}{*}{ NO. } & \multicolumn{2}{|c|}{ Concentration $\mu \mathrm{g} / \mathrm{ml}$} & \multirow{2}{*}{$\%^{*}$} & REC\% & RSD $^{*}$ \\
\cline { 2 - 3 } & present & Found & & & \\
\hline 1 & 8.000 & 8.028 & 0.350 & 100.350 & 0.143 \\
\hline 2 & 16.000 & 15.887 & -0.711 & 99.289 & 0.266 \\
\hline 3 & 25.000 & 25.011 & 0.044 & 100.044 & 0.123 \\
\hline
\end{tabular}

\section{Stoichiometry of the formed product}

thestoichemistry of the formed product was investigated by mole ratio and continuous variation (Job's method), and slope ratio methods .In the mole 
ration method increased volumes of $(20 \mathrm{mM})$ metol were added to a $(1 \mathrm{ml})$ of $(20 \mathrm{mM})$ Ranitidine- $\mathrm{HCl}$ in a series of $(10 \mathrm{ml})$ volume flasks, followed by $1 \mathrm{ml}$ of $20 \mathrm{mM}$ potassium hexacyanoferrate (III), the volumes were made up to the mark with distill water, allowed to stand to $15 \mathrm{~min}$. and the absorbance were measured at $540 \mathrm{~nm}$ versus the reagent blanks. The results were plotted as shown in (Fig.10-11) which indicated the existence of 1:1 metol: Ranitidine-HCl.

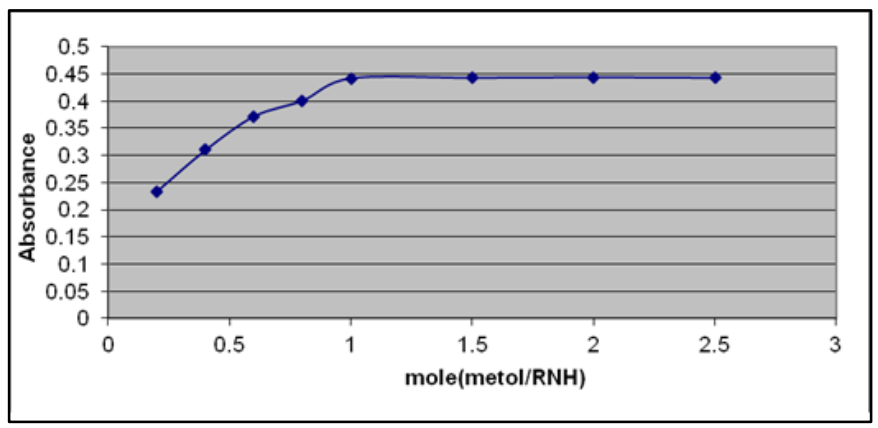

Fig. 9. Mole ratio plot

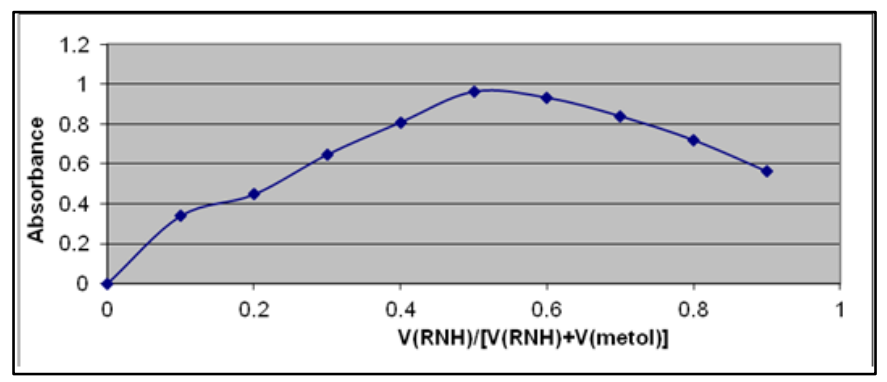

Fig. 10: Continuous variation plots

\section{Pharmaceutical application \\ Evaluation of the proposed method}

The proposed method was applied to the determination of Ranitidine- $\mathrm{HCl}$ (tablet) in proprietary drugs purchased from local stores. The results, shown in Table 4, suggest that the method is suitable for the determination of aspirin and that the excipient in the dosage forms do not interfere.
Table4. Application of the proposed to determination of Ranitidine- $\mathrm{HCl}$ in pharmaceutical tablet

\begin{tabular}{|c|c|c|c|c|c||}
\hline \hline \multirow{2}{*}{$\begin{array}{c}\text { Pharmaceutical } \\
\text { Tablet }\end{array}$} & \multicolumn{2}{|c|}{ Conc. $\mu \mathrm{g} / \mathrm{ml}$} & \multirow{2}{*}{ E \%* } & \multirow{2}{*}{ Rec\%* } & \multirow{2}{*}{ RSD\%* } \\
\cline { 2 - 3 } & Present & Found & & & \\
\hline Samara factory & 8.000 & 8.027 & 0.336 & 100.336 & 0.199 \\
\hline & 16.000 & 16.031 & 0.193 & 100.193 & 0.025 \\
\hline & 25.000 & 25.070 & 0.258 & 100.025 & 0.014 \\
\hline $\begin{array}{c}\text { Julpharlimited } \\
\text { company }\end{array}$ & 8.000 & 8.160 & 1.961 & 101.961 & 0.193 \\
\hline & 16.000 & 16.040 & 0.249 & 100.249 & 0.025 \\
\hline & 25.000 & 24.920 & -0.321 & 99.679 & 0.014 \\
\hline $\begin{array}{c}\text { Global limited } \\
\text { company }\end{array}$ & 8.000 & 8.040 & 0.498 & 100.498 & 0.199 \\
\hline & 16.000 & 16.042 & 0.262 & 100.262 & 0.025 \\
\hline & 25.000 & 24.960 & -0.160 & 99.84 & 0.014 \\
\hline $\begin{array}{c}\text { Ranbaxy limited } \\
\text { company }\end{array}$ & 8.000 & 8.029 & 0.361 & 100.361 & 0.199 \\
\hline & 16.000 & 16.020 & 0.125 & 100.125 & 0.025 \\
\hline & 25.000 & 25.070 & 0.279 & 99.721 & 0.014 \\
\hline \hline
\end{tabular}

* Average of five determinations

\section{Applicability of the proposed method}

The proposed method was applied to determin of aspirin in pharmaceutical formulations purchased from local stores.The \% recoveries of the studied drug compared with that obtained by the standard method are given in Table 4.The methods performance was assessed using the t-test for $95 \%$ confidence level with degree of freedom $\mathrm{n} 1+\mathrm{n} 2-2=8$ and variance ratio $\mathrm{F}$ value test for $95 \%$ confidence level with degree of freedom $\mathrm{n}-1=4$ compared with standard method .Statistical analysis of the results showed that calculated $\mathrm{t}$ - and $\mathrm{F}$ - values at $95 \%$ confidence levels are less than the theoretical ones, confirming no significant differences between the performance of the proposed and standard method in table-5.

Table 5: Comparison of the proposed method with standard method using $\mathrm{t}$ - and $\mathrm{F}$ - value

\begin{tabular}{|c|c|c|c|c|c|c|c|}
\hline No. & Standa & 1 method & Propose & method & & $\mathrm{Va}$ & lue \\
\hline $\begin{array}{c}\text { Origin of } \\
\text { Ranitidinetablet }\end{array}$ & $\begin{array}{c}\operatorname{Rec} \% * \\
\quad X i\end{array}$ & $\left(\mathrm{X}_{\mathrm{i}}-\overline{\mathrm{X}}\right)^{2}$ & $\begin{array}{l}\operatorname{Rec} \% \\
\left(\mathrm{Xi}_{2}\right)^{*}\end{array}$ & $\left(\mathrm{X}_{\mathrm{i}}-\overline{\mathrm{X}}\right)^{2}$ & $\mathrm{~S}$ & $t-* *$ & $F_{-* *}$ \\
\hline Pure & 100.000 & 0.011 & 100 & 0.053 & \multirow{5}{*}{0.05} & \multirow{5}{*}{$\begin{array}{l}0.8495 \\
(2.306)\end{array}$} & \multirow{5}{*}{$\begin{array}{r}0.966 \\
(9.605)\end{array}$} \\
\hline Samara factory & 99.700 & 0.038 & 99.913 & 0.001 & & & \\
\hline $\begin{array}{l}\text { Global limited } \\
\text { company }\end{array}$ & 99.925 & 0.001 & 99.683 & 0.157 & & & \\
\hline $\begin{array}{l}\text { Julpharlimited } \\
\text { company }\end{array}$ & 100.225 & 0.1089 & 99.383 & 0.001 & & & \\
\hline \multirow[t]{2}{*}{$\begin{array}{c}\text { Ranbaxy } \\
\text { limited } \\
\text { company }\end{array}$} & 99.625 & 0.072 & 99.243 & 0.026 & & & \\
\hline & $\overline{\mathrm{X}}=99.895$ & $\Sigma=0.231$ & $\bar{X}=99.644$ & $\Sigma=0.239$ & \multicolumn{2}{|c|}{$n_{1}+n_{2}-2=8$} & $\begin{array}{l}n_{1}-1=4 \\
n_{2}-1=4\end{array}$ \\
\hline
\end{tabular}

* Average of five determinations, ** Theoretical t- and F- values at 95\% confidence level 2.306 and 9.605, respectively 


\section{Interference study}

pharmaceutical analysis, it is important to test theselectivity towards theexcipients added to the pharmaceuticalpreparations.Commonlyencounteredexci pients such as glucose, lactose starch and Talcs did not interfere in the determination of $\mathrm{RNH}$. This gave an important advantage to the proposed pharmaceutical analysis, it is important to test the selectivity towards method.

\section{Conclusion}

Despite the great number of methods described in the literature for analysis of Ranitidine- $\mathrm{HCl}$, the proposed method for the determination of Ranitidine- $\mathrm{HCl}$ in pharmaceutical samples have the advantage to be simple, sensitive, accurate and inexpensive. The method represented good accuracy and precision so that the respective relative standard deviation and relative error of prediction for drug were lower. The proposed method was applied successfully to analysis of drugs in tablets and thus is very appropriate for routine quality control analysis of drug.

\section{References}

1- BadiadkaNarayana, Krishnamurthy Ashwini, DivyaNarayanaShetty, Kunnummel ,2010 "

Spectrophotometric Determination of Ranitidine Hydrochloride Based on the Reaction with p-Dimethylaminobenzaldehyde"Eurasian J. Anal. Chem. 5(1) p.63-72.

2-S. Khalil , S.A. Ibrahim2, F.I. Zedan and M.S. AbdEl-monem AAS, 2005 "Determination of Bromhexine, Flunarizine and Ranitidine Hydrochlorides in Pharmaceutical

Formulations " Chem. Anal. Warsaw , 50, p.897

3-AnetaSok, Joanna Karpi- Ska, Retalecka and Barbara Starczewskawata ,2011 "

quantification of Ranitidine hydrochloride in the presence of its decomposition product by spectrophotometric methods application for kinetic study" ActaPoloniaePharmaceutica n Drug Research, Vol. 68 No. 2 p. 169-177.

4- Mohammed Ibrahim Walash, Mohie Khalid SharafEl-,Din, Mohammed El-

SayedMetwallyand MostafaRedaShabana, 2004 " Kinetic Spectrophotometric

Determination of Ranitidine"Journal of the Chinese Chemical Society 51p.523-530.

5- M D Ahsanul Haque, Mohammed Shahriar, Most Nazma Parvin and S. M. Ashraful Islam "Validation RP- HPLC method for estimation of ranitidine hydrochloride ,
Domperridone and Naproxen in solid phase Dosage form" 2011 Asian J. Pharm Ana., V.1, N.3, p.59-63.

6- Sevgi Tatar Ulu1and MuzafferTuncel, A Sensitive and Rapid "Determination of

anitidine in Human Plasma by HPLC with Fluorescence Detection and its Application for a Pharmacokinetic Study",2012 Journal of Chromatographic Science,30, p.1-6.

7- Khadiga M. Kelani, Azza M. Aziz, Maha A. Megazy\&Laila Abdel , 2002 "Determination of

Cimetidine, Famotidine, and Ranitidine Hydrochloride in the Presence of Their Sulfoxide Derivatives inPure and Dosage Forms by High-Performance Thin-layer Chromatography and Scanning Densitometry" Journal of AOAC International V. 85, p. 5.

8- Mukesh Chandra Sharma, Smita Sharma Forced,2011 "Degradation Studies and Micellar Liquid Chromatographic Method Developmentfor Determination of Ranitidine hydrochloride in Tablet dosage" international Journal of ChemTechResearch Vol. 3, No.1, p. 199-202.

9 -Zhang Chao, Wang Lu , Guan Xin1, J. Paul Fawcett , Zhao Li-mei Sun Yan-tong1 and Gu Jing-kai, 2010 "Rapid Determination of Ranitidine in Human Plasma by Liquid chromatographytandem mass spectrometry and its application to a clinical pharmacokinetic study, Chem. Res. Chinese Universalities, 26(6), 910-914.

10. Karini B. Bellerio, Maria Isabul R. Alves and Nelson R. AntoniosiFilho, 2013, " Determination of Ranitidine in human plasma by SPE and ESILC- MS/MS for use in Bioequivalence studies", ISRN Chromatography p.1-7.

11- NitishSharm, Surendra Singh Rao, NamalaDurgaAtchuta Kumar , Pingili Sunil Reddy, AnnarapuMalleseara Reddy, 2011 " A Validated Stability-Indicating Liquid-

Chromatographic Method for Ranitidine Hydrochloride in Liquid Oral Dosage". http://www.scipharm.at/Sci Pharm, 79, p.309-322.

12- Gao Ying, TianYiling, Sun Xiuhua, Yin Xue-Bo, Xiang Qiani ,2006 "Determination of ranitidine in urine by Capillary electrophoresis with electrochemiluminescent detection" Journal of chromatography B, V.832(2), p.236-240.

13- Carmen Lopez - Erroz, PilarVinas, Natalia Campillo and Manual Hernández- Coroba,1996 
" Flow injection - Fluorimetric method for the determination of ranitidine in

pharmaceutical preparation using OPhathaldehyde, "Analyst, 121, p.1043-1046.

14- Perez Ruiz T., Martinez- Lozano C , Tomas V.andSanz A ,2011 " Flow - injection

exctraction - spectrophotometric method for the determination of ranitidine in

pharmaceutical preparations" Journal of pharmaceutical \& Biomedical Analysis,26(4), p. 609-615.

15- Neil W Barnett, Benjamin J. Hindson and Simon W Lewis, 1999 "Determination Ranitidine and Salbutamol by flow injection Analysis with Chemiluminescencedetection",AnalticaChimicaA cta, V. 384, N.2, p. 151- 158.

16- Norouzi P, Ganjali MR \&Daneshgar P,2007 " A novel method for fast determination of Ranitidine in its Pharmaceutical for mutation by fast continuous cyclic Voltammeter "

Journal of Pharmacological \& toxicological methods, 55(3), p.289- 296.

17- Yousry M. Issa, Sayed S. Badawy\& Ali A. Mutair, 2005 "Ionselectiv electrodes for

potentiometric determination of ranitidine hydrochloride, Applying Batch and flow

injection Analysis techniques" Analytical Sciences, V. 21, p.1443-1448.

18- Eman Y Z Frag, Ahmed M K Mohammed, Gehad G Mohammed \&Ebtesam E Alrahmony, 2011 " Construction \& performance characterization of Ion Selective Electrodes for potentiometric determination of Ranitidine in Pharmaceutical preparations \& Biological fluids" Int. J. Electrochem. Sci., V.6, p.35083524.

19- Palolo Richter, M. Inés Toral and Fernando MuñozVargas , 1994 "Polarographic

behavior \& determination of Ranitidine in pharmaceutical formulation and urine"

Analyst, 119, p. 1371-1374.

20- Andrea R. Malagutti and Luiz H. Mazo , 2003

"Determination of Ranitidine in Drugs

Using a Mercury Coated Platinum Ultramicroelectrode and Hanging Mercury Dropping Electrode", Chem. Soc., Vol. 14, No. 2, p. 274-280.

21- P. Ravi Prasad, K. Bhuvaneswari1, Murarilal1, K. Rajanil ,2012 "Quantitative determination of Domperidone and Ranitidine in combined dosage by FT-IR spectroscopy", Am. J. Pharm Tech. Res., 2(4), p.2249- 3387.

22- S. Khalil , S.A. Ibrahim2, F.I. Zedan and M.S. AbdEl-monem, 2005"AAS Determination of Bromhexine, Flunarizine and Ranitidine Hydrochlorides in Pharmaceutical

Formulations"Chem. Anal. Warsaw , 50, p. 897.

23- K.Basavaiah , B.C. Somashekar, 2007" Argentimetric assay of ranitidine in bulk drug and in dosage Forms" V. 32.

24-BadiadkaNarayana, Krishnamurthy Ashwini, DivyaNarayanaShetty, Kunnummel , 2010" Spectrophotometric Determination of Ranitidine Hydrochloride Basedon the Reaction with $p$ Dimethylaminobenzaldehyde", Eurasian J. Anal. Chem. 5(1) p. 63-72.

25-Amul N. Mishra and A.C. Ranation,2012 " UV spectrophotometric determination of

Ranitidine Hydrochloride in pure and pharmaceutical formula int. J. Chem. Sci. 7(3), p.2208-2210.

26-M. M. Khalila, E. Y. Z. Fragb, Gehad G. Mohamed B. and Gamal M. Abed el Aziza, 2013" Spectrophotometric studies using ion-pair formations ofRanitidine hydrochloride in pure and in Pharmaceutical forms with some dyestuff reagents Journal of Applied Pharmaceutical Science Vol. 3 (4), p. 092-098. 